Indo. J. Chem. Res., 2018, 5(2), 69-74

\title{
AKTIVITAS ANTIOKSIDAN DAN FITOKIMIA DARI EKSTRAK ETIL ASETAT PUCUK IDAT (Cratoxylum glaucum)
}

\author{
Antioxidant Activity and Phytochemical of Extract Ethyl Acetat Pucuk Idat \\ (Cratoxylum glaucum) \\ Robby Gus Mahardika*, Occa Roanisca \\ Departement of Chemistry, Faculty of Engineering, Universitas Bangka Belitung \\ Jl. Kampus Peradaban, Merawang, Bangka, 33172 - Indonesia \\ *Corresponding author, e-mail: robby-gm@kimia.ubb.ac.id
}

Received: Nov. 2017 Published: Jan. 2018

\begin{abstract}
Free radicals are one cause of cancer, coronary heart disease, rheumatism, and some other degenerative diseases. Neutralizing free radicals can use both synthetic and natural antioxidant compounds. Although synthetic antioxidant compounds are more active, but lately the use of synthetic antioxidants is being reduced because they are reported to have carcinogenic side effects. Therefore, it is necessary to develop a natural antioxidant tracking of plant extracts. Natural antioxidant compounds found in plants are phenolic groups such as flavonoids, tannins, xanthones, and anthraquinones. This compound is widely found in the genus Cratoxylum where one of the species is pucuk idat (Cratoxylum glaucum). Pucuk idat are often used by people of Bangka as a flavoring dish and are believed to be traditional medicine to facilitate breastfeeding, tighten skin, treat fever, cough, and diarrhea. The increasing of antioxidants needs and lots efficacy of pucuk idat, hence this study aims to determine the antioxidant activity of ethyl acetate extract Cratoxylum glaucum. The antioxidant test in this study used the DPPH (Diphenylpicrylhydrazyl) method and vitamin C as a positive control. The results of this study indicate that the extract of ethyl acetate Cratoxylum glaucum has strong antioxidant activity with value $\mathrm{IC}_{50} 32,213 \mu \mathrm{g} /$ $\mathrm{mL}$. Phytochemical content itself includes hydroquinone phenols (tannins), flavonoids, and steroids. This shows that ethyl acetate extract Cratoxylum glaucum can be used as natural antioxidant.
\end{abstract}

Keywords: Antioxidant, Cratoxylum glaucum, ethyl acetate extract

\section{PENDAHULUAN}

Radikal bebas dalam tubuh dengan jumlah besar dapat menyebabkan beberapa penyakit yaitu kanker, aterosklerosis, rematik, jantung koroner, dan bebrapa penyakit degeneratif (Toripah dkk., 2014). Hal ini karena radikal bebas dapat menyebabkan peroksidasi dan penurunan fluiditas membran, sehingga menyebabkan kerusakan dan inaktivasi membran. Radikal bebas juga dapat menyerang DNA dan dapat menyebabkan mutasi yang menyebabkan kanker (Cooper dkk., 2004). Oleh sebab itu perlu senyawa yang dapat menetralkan radikal bebas tersebut.

Salah satu senyawa yang dapat menetralisir radikal bebas dan menghambat laju oksidasi yaitu antioksidan (Fajriah dkk., 2012). Menurut Winarsi dkk., (2007), antioksidan bersifat sangat mudah teroksidasi atau bersifat reduktor kuat dibanding dengan molekul yang lain. Karena sifatnya yang mudah teroksidasi, maka antioksidan sering digunakan oleh industri makan sebagai zat aditif untuk meningkatkan nilai gizi, melindungi makanan agar tidak mudah rusak, dan terapeutik (Carocho dkk., 2014; Karaaslan dkk., 2011; Shori dkk., 2013). Antioksidan juga digunakan untuk meningkatkan kualitas biodisel dan minyak kelapa (Focke, 2012; Hermiati dkk, 2013). Manfaat antioksidan yang banyak dan diiringi dengan meningkatnya jumlah penduduk sehingga membuat kebutuhan akan antioksidan semakin meningkat (Fitri, 2014). Oleh sebab itu dilakukan berbagai cara untuk mendapatkan antioksidan lebih cepat dan dalam jumlah banyak yaitu dengan sintesis.

Senyawa antioksidan hasil sintesis yaitu Butil Hidroksi Anisol (BHA), Butil Hidroksi Toluen (BHT), $t$-Butil Hidroksi Kuinon (TBHQ), propil galat, dan analog alfa tokoferol. Antioksidan tersebut telah digunakan secara luas dan mempunyai aktivitas antioksidan yang kuat (Madhavi dkk., 1995). Tetapi, beberapa 
Robby G. M. dkk. / Indo. J. Chem. Res., 2018, 5(2), 69-74

penelitian melaporakan bahwa antioksidan sintetik mempunyai toksisitas cukup tinggi dan bersifat karsinogen (Branen, 1975; Caleja dkk., 2017; Reddy dkk., 2005). Hal ini menyebabkan penggunaan antioksidan sintetik mulai dikurangi dan beralih menggunakan antioksidan alami.

Antioksidan alami dapat berasal dari tumbuh-tumbuhan yang banyak mengandung vitamin $\mathrm{C}$, beta karoten, dan senyawa polifenol seperti flavonoid, fenil propanoid, santon, antrakuinon, lignan (Cutler dkk., 2000; Lisdawati dkk., 2006). Tetapi untuk mendapatkan antioksidan alami dalam jumlah banyak dengan aktivitas yang kuat tidaklah mudah, karena tidak semua tumbuhan mempunyai aktivitas antioksidan tinggi. Oleh sebab itu, perlu dikembangkan penelusuran ekstrak tumbuhan yang mempunyai aktivitas antioksidan tinggi.

Ekstrak tumbuhan yang dikenal aktif sebagai antioksidan adalah manggis (Garcinia mangostana). Manggis banyak mengandung senyawa fenolik dimana metabolit mayornya adalah antrakuinon dan santon (Chin dkk., 2008). Penelitian yang telah dilakukan, kandungan metabolit sekunder mayor yang ditemukan pada Cratoxylum glaucum meliputi antrakuinon dan santon (Rahmani dkk., 2007). Kemiripan kandungan metabolit sekunder pada spesies yang berbeda akan memiliki bioaktivitas yang hampir sama. Sehingga Cratoxylum glaucum yang dikenal oleh masyarakat Bangka Belitung dengan nama Pucuk Idat ini memiliki aktivitas antioksidan yang sama dengan manggis (Garcinia mangostana).

Kajian fitokimia dan bioaktivitas yang telah dilakukan hanya terbatas pada Cratoxylum glaucum dari Sabah dan Sarawak (Rahmani dkk., 2007), sedangkan Cratoxylum glaucum dari Indonesia belum ada pengkajian. Pucuk Idat (Cratoxylum glaucum) sendiri sangat sering digunakan oleh masyarakat sebagai obat tradisional untuk memperlancar ASI, mengencangkan kulit, mengobati demam, batuk, dan diare oleh masyarakat Bangka Belitung. Kebutuhan antioksidan yang semakin meningkat dan khasiat dari pucuk idat yang banyak maka penelitian ini bertujuan untuk mengetahui aktivitas antioksidan ekstrak etil asetat Cratoxylum glaucum.

\section{METODOLOGI}

\section{Bahan}

Pada penelitian ini bahan-bahan yang digunakan meliputi daun Pucuk idat (Cratoxylum glaucum), kertas saring Whatman no 1, aluminium foil, aseton, metanol, etanol p.a, kloroform, n-heksana, $\mathrm{H}_{2} \mathrm{SO}_{4}$ pekat, asam asetat glasial, $\mathrm{FeCl}_{3}, \mathrm{HCl}$, serbuk $\mathrm{Mg}$, pereaksi Mayer, pereaksi Wagner dan aqudest.

\section{Alat}

Penelitian ini Alat-alat yang digunakan dalam penelitian ini meliputi erlenmayer, gelas ukur, corong Büchner, rotary evaporator, neraca analitik, pipet tetes, tabung reaksi, batang pengaduk, spatula, labu ukur, rak tabung reaksi, spekrofotometer UV-Vis 1800 Shimadzu dan hot plate.

\section{Preparasi Sampel}

Daun pucuk idat (Cratoxylum glaucum) yang digunakan dalam penelitian ini berasal dari Desa Sempan, Kecamatan Pemali, Kabupaten Bangka, Kepulauan Bangka Belitung. Sampel selanjutnya dikeringkan dan dihaluskan menjadi serbuk kering yang kemudian dimaserasi menggunakan pelarut etil asetat.

\section{Ekstraksi}

Serbuk kering daun pucuk idat (Cratoxylum glaucum) sebanyak 65 gram kemudian dimaserasi dengan pelarut etil asetat sebanyak $650 \mathrm{~mL}$. Filtrat dan residu dipisahkan menggunakan corong büchner. Filtrat yang diperoleh dipekatkan menggunakan rotary evaporator yang selanjutnya dilakukan uji fitokimia dengan beberapa metode uji meliputi uji fenol hidrokuinon, flavonoid, alkaloid, saponin, steroid, dan terpenoid (Lisdawati dkk., 2006).

\section{Uji Aktivitas Antioksidan}

Uji aktivitas antioksidan dilakukan secara kualitatif dan kuantitatif. Pengujian antioksidan secara kualitatif pada penelitian ini menggunakan plat KLT (kromatografi lapis tipis) dengan penyemprotan larutan DPPH 0,2\%. Jika mempunyai aktivitas antioksidan warna DPPH dari ungu pada plat KLT berubah menjadi kuning (Molyneux, 2004). 
Pengujian antioksidan secara kuantitatif menggunakan metode DPPH dengan pengukuran secara spektroskopi. Terlebih dahulu dicari panjang gelombang maksimum DPPH 100 $\mu \mathrm{g} / \mathrm{mL}$. Kontrol positif digunakan vitamin $\mathrm{C}$ dengan konsentrasi $1,3,5,6$, dan $8 \mu \mathrm{g} / \mathrm{mL}$. Sedangkan ekstrak etil asetat pucuk idat (Cratoxylum glaucum) dibuat dalam konsentrasi $1,3,5,8$, dan $10 \mu \mathrm{g} / \mathrm{mL}$. Masing-masing konsentrasi dimasukkan dalam tabung reaksi sebanyak $1 \mathrm{~mL}$ dan ditambahkan larutan DPPH $100 \mu \mathrm{g} / \mathrm{mL} 1 \mathrm{~mL}$ serta metanol p.a. $2 \mathrm{~mL}$. Larutan yang telah ditambah DPPH diinkubasi selama 30 menit pada suhu $37^{\circ} \mathrm{C}$. Larutan terseut diukur absorbansinya menggunakan spektroskopi UV-Vis 1800 Shimadzu pada panjang gelombang maksimum. Aktivitas antioksidan dinyatakan dalam $\mathrm{IC}_{50}$ dengan menghitung persentase inhibisi dari masing-masing konsenrasi larutan sampel dengan rumus :

$\%$ Inhibisi $=\frac{A_{\text {blanko }}-A_{\text {sampel }}}{A_{\text {blanko }}} \times 100 \%$

$\mathrm{IC}_{50}$ yang didapat dari nilai $\mathrm{x}$ dengan $\mathrm{y}=50$ dari hasil persamaan regresi linier antara persentase inhibisi dengan konsentrasi (Lisdawati $d k k ., 2006$ ).

\section{HASIL DAN PEMBAHASAN}

Cratoxylum glaucum termasuk dalam famili Hipericaceae yang merupakan salah satu golongan tumbuhan berbunga dan berbiji tertutup. Spesies ini merupakan salah satu tumbuhan semak atau pohon kecil. Penyebaran di Indonesia meliputi daerah Sumatera, Bangka, Belitung, dan Kepulauan Natuna. Cratoxylum glaucum dikenal dengan nama Pucuk Idat oleh masyarakat Bangka Belitung. Daun pucuk idat berbentuk bulat dengan ukutan $2-5 \times 1,5-3 \mathrm{~cm}$ yang berwarna hijau diatasnya dan berwarna keabu-abuan dibawahnya (Wong, 2007) Gambar 1. Daun mudanya sering digunakan untuk penyedap makanan oleh masyarakat Bangka Belitung.

Pada penelitian ini Cratoxylum glaucum diekstraksi menggunakan pelarut etil asetat. Penggunaan etil asetat yang bersifat semipolar harapannya dapat mengekstrak metabolit sekunder yang bersifat polar maupun non polar. Ekstrak tersebut yang selanjutnya dilakukan uji fitokimia dan uji aktivitas antioksidan. Pengujian fitokimia ekstrak etil asetat Cratoxylum glaucum pada penelitian ini menggunakan beberapa metode uji meliputi uji alkaloid, fenol hidrokuinon, flavonoid, saponin dan steroid.

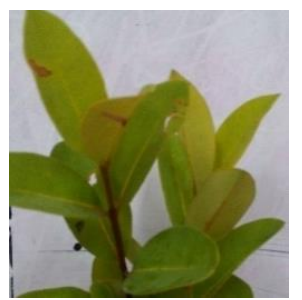

Gambar 1. Daun pucuk idat

Adanya golongan senyawa fenol hidrokuinon (tanin) diketahui dari hasil uji $\mathrm{FeCl}_{3}$ yang menunjukkan terbentuk warna hijau atau hijau kebiruan. Hal menandakan bahwa terdapat senyawa fenol hidrokuinon dari ekstrak etil asetat Cratoxylum glaucum. Hasil uji flavonoid menggunakan metode uji Wilstater Sianidin menujukkan bahwa terdapat senyawa flavonoid pada ekstrak etil asetat pucuk idat yang ditunjukkan dengan warna jingga.

Golongan senyawa steroid diidentifikasi dengan metode uji Liebermannn-Burchard, hasil uji ini menunjukkan uji positif dengan terbentuknya warna hijau tua. Sedangkan pengujian alkaloid dan saponin menunjukkan menujukkan hasil uji negatif. Jadi, dari hasil uji fitokimia yang dilakukan menunjukkan bahwa ekstrak etil asetat Cratoxylum glaucum mengandung golongan senyawa fenol hidrokuinon, flavonoid, dan steroid. Hasil uji fitokimia ekstrak etil asetat Cratoxylum glaucum disajikan pada Tabel 1.

Tabel 1 Hasil uji fitokimia ekstrak etil asetat pucuk idat (Cratoxylum glaucum)

\begin{tabular}{|c|c|c|c|}
\hline Uji & $\begin{array}{c}\text { Metode } \\
\text { Pengujian }\end{array}$ & Hasil & Ket. \\
\hline \multirow[t]{2}{*}{ Alkaloid } & Mayer & $\begin{array}{l}\text { Tidak terbentuk } \\
\text { endapan putih } \\
\text { kekuningan }\end{array}$ & - \\
\hline & Wagner & $\begin{array}{l}\text { Tidak terbentuk } \\
\text { endapan coklat }\end{array}$ & - \\
\hline $\begin{array}{l}\text { Fenol } \\
\text { hidrokuinon } \\
\text { (Tanin) }\end{array}$ & $\mathrm{FeCl}_{3}$ & $\begin{array}{l}\text { Terbentuk warna } \\
\text { hijau atau hijau } \\
\text { biru }\end{array}$ & + \\
\hline Flavonoid & $\begin{array}{l}\text { Uji } \\
\text { Wilstater } \\
\text { sianidin }\end{array}$ & $\begin{array}{l}\text { Terbentuk warna } \\
\text { jingga. }\end{array}$ & + \\
\hline Saponin & Uji Forth & Tidak ada busa & - \\
\hline Steroid & $\begin{array}{l}\text { Uji } \\
\text { Liebermann } \\
\text { - Burchard }\end{array}$ & $\begin{array}{l}\text { Terbentuk warna } \\
\text { hijau tua }\end{array}$ & + \\
\hline
\end{tabular}


Robby G. M. dkk. / Indo. J. Chem. Res., 2018, 5(2), 69-74

Tabel 2 Hasil Pengujian Antioksidan Ekstrak Etil Asetat Pucuk idat (Cratoxylum glaucum)

\begin{tabular}{|c|c|c|c|c|c|c|c|}
\hline \multirow{2}{*}{ Sampel } & \multirow{2}{*}{$\begin{array}{c}\text { Konsentrasi } \\
(\mu \mathrm{g} / \mathrm{mL})\end{array}$} & \multicolumn{2}{|c|}{ Absorbansi } & \multirow{2}{*}{$\begin{array}{c}\% \\
\text { In hibisi }\end{array}$} & \multirow{2}{*}{$\begin{array}{c}\text { Persamaan } \\
\text { Linier }\end{array}$} & \multirow{2}{*}{$\begin{array}{c}\mathrm{IC}_{\mathbf{5 0}} \\
(\mu \mathrm{g} / \mathrm{mL})\end{array}$} & \multirow{2}{*}{ Ket. } \\
\hline & & Blanko & Sampel Uji & & & & \\
\hline \multirow{5}{*}{ Vitamin $C$} & 1 & & 0,524 & 7,257 & \multirow{5}{*}{$\begin{array}{c}\mathrm{y}=4,0162 \mathrm{x}+ \\
1,4899 \\
\mathrm{R}^{2}=0,9815\end{array}$} & \multirow{5}{*}{12,078} & \multirow{5}{*}{$\begin{array}{c}\text { Sangat } \\
\text { Kuat }\end{array}$} \\
\hline & 3 & & 0,501 & 11,327 & & & \\
\hline & 5 & 0,565 & 0,445 & 21,239 & & & \\
\hline & 6 & & 0,421 & 25,487 & & & \\
\hline & 8 & & 0,370 & 34,513 & & & \\
\hline \multirow{5}{*}{$\begin{array}{l}\text { Ekstrak Etil } \\
\text { A setat } \\
\text { Cratoxylum } \\
\text { glaucum }\end{array}$} & 1 & & 0,631 & 3,664 & \multirow{5}{*}{$\begin{array}{c}\mathrm{y}=1,4309 \mathrm{x}+ \\
3,9069 \\
\mathrm{R}^{2}=0,9378\end{array}$} & \multirow{5}{*}{32,212} & \multirow{5}{*}{$\begin{array}{c}\text { Sangat } \\
\text { Kuat }\end{array}$} \\
\hline & 3 & & 0,594 & 9,313 & & & \\
\hline & 5 & 0,665 & 0,572 & 12,672 & & & \\
\hline & 8 & & 0,557 & 14,962 & & & \\
\hline & 10 & & 0,54 & 17,557 & & & \\
\hline
\end{tabular}

\section{Aktivitas Antioksidan Ekstrak Etil Asetat Pucuk idat}

Uji aktivitas antioksidan ekstrak etil asetat Cratoxylum glaucum pada penelitian ini menggunakan metode DPPH. Uji kualitatif menggunakan plat KLT yang disemprotkan DPPH $0,01 \%$ dengan eluen kloroform : metanol (50:1). Sedangkan uji kuantitatifnya secara spektroskopi. Berdasarkan hasil uji kualitatif menunjukkan bahwa adanya senyawa yang bertindak sebagai antioksidan yang dibuktikan dengan berubahnya warna ungu DPPH menjadi warna kuning pada spot (noda) di KLT (Gambar 2). Hal ini menunjukkan bahwa ekstrak etil asetat Cratoxylum glaucum dapat bertindak sebagai antioksidan.

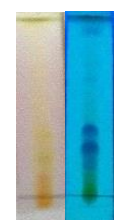

Gambar 2 Hasil uji kualitatif menggunakan plat KLT yang disemprot larutan DPPH 0,01\% dengan eluen kloroform: metanol (50:1)

Penggunaan metode DPPH dipilih karena metode ini sederhana, mudah, cepat dan memerlukan sedikit sampel. Radikal DPPH akan mudah bereaksi dengan senyawa antioksidan melalui mekanisme donor atom hidrogen yang menyebabkan terjadi perubahan warna DPPH dari ungu menjadi kuning yang diukur pada panjang gelombang $516 \mathrm{~nm}$ (Hanani $d k k$., 2005). Berdasarkan hasil pengukuran absorbansi maksimum dari DPPH $100 \mu \mathrm{g} / \mathrm{mL}$ didapatkan panjang gelombang maksimum $516 \mathrm{~nm}$. Panjang gelombang $516 \mathrm{~nm}$ ini yang akan digunakan untuk mengukur absorbansi sampel ekstrak etil asetat Cratoxylum glaucum dan vitamin C menggunakan spektrofotometer UV-Vis.

Berdasarkan hasil pengkuran absorbansi DPPH terhadap sampel ekstrak dan vitamin C menunjukkan bahwa semakin meningkatnya konsentrasi sampel semakin turun absorbansi DPPH. Hal ini menunjukkan bahwa adanya senyawa yang dapat memberikan radikal hidrogen pada radikal bebas DPPH. Hasil aktivitas antioksidan disajikan pada Tabel 2.

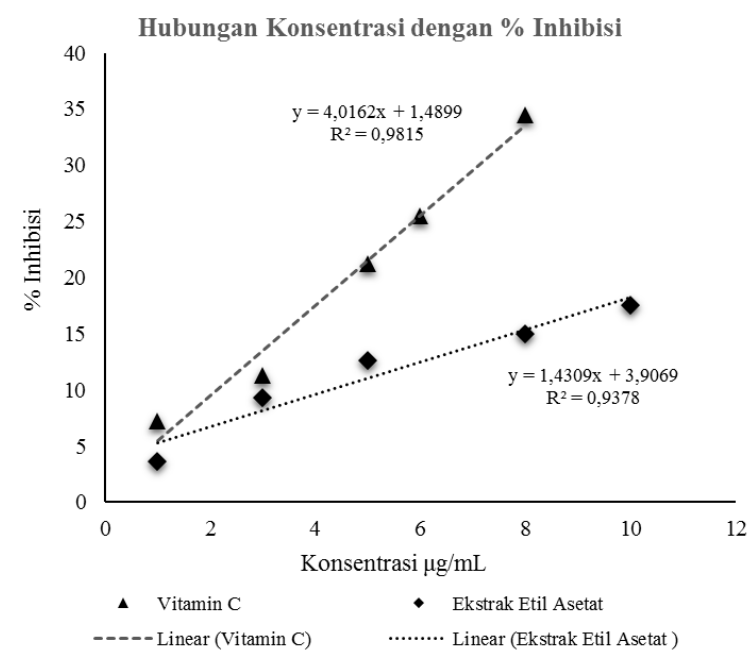

Gambar 3 Kurva Hubungan Konsentrasi dengan $\%$ Inhibisi

Aktivitas antioksidan diukur melalui $\mathrm{IC}_{50}$ yang diturunkan dari persamaan linier antara inhibisi dan konsentrasi (Gambar 3). Aktivitas ekstrak etil asetat pucuk idat (Cratoxylum glaucum) mempunyai nilai $\mathrm{IC}_{50}$ sebesar 32,212 $\mu \mathrm{g} / \mathrm{mL}$. Sedangkan Vitamin C sebagai kontrol positif mempunyai nilai $\mathrm{IC}_{50}$ sebesar 12,092 $\mu \mathrm{g} / \mathrm{mL}$. Nilai $\mathrm{IC}_{50}$ vitamin $\mathrm{C}$ lebih rendah dibandingkan ekstrak etil asetat, berarti vitamin C lebih aktif sebagai antioksidan jika 
dibandingkan dengan ekstrak etil asetat pucuk idat.

Menurut Suratmo (2009) dalam Putri $d k k$. (2015) kekuatan antioksidan dikelompokkan berdasarkan nilai $\mathrm{IC}_{50}$. Jika dikatakan sangat aktif sebagai antioksidan maka nilai $\mathrm{IC}_{50}<50 \mu \mathrm{g} / \mathrm{mL}$, kuat $50-100 \mu \mathrm{g} / \mathrm{mL}$, sedang $100-250 \mu \mathrm{g} / \mathrm{mL}$, dan lemah 250-500 $\mu \mathrm{g} / \mathrm{mL}$. Maka nilai $\mathrm{IC}_{50}$ dari ekstrak etil asetat pucuk idat dikatagorikan sebagai aktivitas antioksidan sangat kuat dengan nilai $\mathrm{IC}_{50}<50 \mu \mathrm{g} / \mathrm{mL}$.

Apabila dihubungkan antara aktivitas antioksidan ekstrak etil asetat pucuk idat dengan hasil kajian fitokimia. Aktivitas antioksidan ekstrak etil asetat pucuk idat yang sangat kuat ini disebabkan oleh adanya senyawa fenol hidrokuinon dan flavonoid dalam ekstrak tersebut. Senyawa fenol hidrokuinon dan flavonoid merupakan senyawa polifenol yang mudah mendonorkan hidrogen radikal sehingga sangat baik sebagai senyawa antioksidan. Akan tetapi pengujian antioksidan pada penelitian ini hanya pada esktrak kasar etil asetat pucuk idat, sehingga memungkinkan senyawa murni yang terkandung dalam pucuk idat memiliki aktivitas antioksidan yang lebih tinggi dibandingkan ekstrak kasarnya.

\section{KESIMPULAN}

Berdasarkan penelitian yang dilakukan, ekstrak etil asetat pucuk idat (Cratoxylum glaucum) dari Pulau Bangka mempunyai kandungan fitokimia fenol hidrokuinon, flavonoid, dan steroid. Ekstrak ini memiliki aktivitas antioksidan yang sangat kuat dengan nilai $\mathrm{IC}_{50} 32,212 \mu \mathrm{g} / \mathrm{mL}(<50 \mu \mathrm{g} / \mathrm{mL})$. Hal ini menunjukkan bahwa ekstrak etil asetat pucuk idat berpotensi sebagai antioksida alami untuk menangkal radikal bebas.

\section{UCAPAN TERIMA KASIH}

Peneliti mengucapkan terima kasih kepada Rektor Universitas Bangka Belitung yang telah memberikan bantuan dana penelitian berdasarkan SK Rektor No. 1348/UN50/PL/2017

\section{DAFTAR PUSTAKA}

Branen, A. (1975). Toxicology and biochemistry of butylated hydroxyl anisole and butylated hydroxytoluene. Journal of American Oil Chemists Society, 59-63, 52.

Caleja, C., Barros, L., Antonio, A.L., Oliveira, M., \& Ferreira, I.C.F.R. (2017). A comparative study between natural and synthetic antioxidants: Evaluation of their performance after incorporation into biscuits. Food Chemistry, 216, 342-346.

Carocho, M., Barreiro, M. F., Morales, P., \& Ferreira, I. C. F. R. (2014). Adding molecules to food, pros and cons: A review of synthetic and natural food additives. Comprehensive Reviews in Food Science and Food Safety, 13, 377-399.

Chin, Y., Hyun-Ah J., \& Chai H. (2008). Xanthones with quinone reductase-inducing activity from the fruits of Garcinia mangostana (Mangosteen). Phytochemistry, 69, 754-758.

Cooper, G.M., \& Hausman, R.E. (2004). The Cell: A Molecular Approach (3 ed.). Sunderland: Masschusetts.

Cutler, S.J. \& Cutler, H. (2000). Biologically Active Natural Products: Pharmaceuticals. New York: CRC Press.

Fajriah, S., Darmawan, A., Sundowo, A., \& Artanti, N. (2012). Isolasi senyawa antioksidan dari ekstrak etil asetat daun benalu (Dendrophthoe pentandra L.Miq) yang tumbuh pada Inang Lobi-Lobi. Jurnal Kimia Indonesia, 2, 17-20.

Fitri, N. (2014). Butylated hydroxyanisole sebagai bahan aditif antioksidan pada makanan dilihat dari prespektif kesehatan. Jurnal Kefarmasian Indonesia, 4, 41-50.

Focke, W. W. (2012). The effect of synthetic antioxidants on the oxidative stability of biodiesel. Fuel, 94, 227-233.

Hanani, E., Mun'im, A., Sekarini, R. (2005). Identifikasi senyawa antioksidan dalam spons Callyspongia sp dari kepulauan seribu. Majalah Ilmu kefarmasian, 2, 127133.

Hermiati, Rusli, Manalu, N.Y., \& Sinaga, M.S. (2013). Ekstrak daun sirih hijau dan merah sebagai antioksidan pada minyak kelapa. Jurnal Teknik Kimia USU, 2, 37-43.

Karaaslan, M., Ozden, M., Vardin, H., \& Turkoglu, H. (2011). Phenolic fortfication of yogurt using grape and callus Extracts. Food Science Technology, 44, 1065-1072. 
Robby G. M. dkk. / Indo. J. Chem. Res., 2018, 5(2), 69-74

Lisdawati, V., \& Kardono, B.S. (2006). Aktivitas antioksidan dari berbagai fraksi ekstrak daging buah dan kulit biji mahkota dewa (Phaleria macrocarpa). Media Litbang Kesehatan, 16, 1-7.

Madhavi, D.L., Deshpande, S.S., \& Salunkhe, D.K. (1995). Food Antioxidant: Technologycal: Toxicology and Health Perspectives. New York: CRC Press .

Molyneux, P. (2004). The use of the stable free radical diphenyl picrylhidrazyl (DPPH) for estimating antioxidant activity. Songklanakarin Journal of Science and Technology, 26, 211-219.

Putri, A.A.S., Hidajati, N. (2015). Uji aktivitas antioksidan senyawa fenolik ekstrak metanol kulit batang tumbuhan nyiri batu (Xylocarpus moluccensisi). UNESA Journal of Chemistry, 4. 1-6.

Rahmani, M. \&, Taufiq Y.H. (2007). Compounds From Cratoxylum aborescens, Cratoxylum glaucum, Garcinia nitida and Garcinian mangostana and their Potential as Anti-Cancer Lead Compounds. Pertanika Journal of Science \& Technology, 1(15), 43-47.
Reddy, V., Urooj, A., \& Kumar, A. (2005). Evaluation of antioxidant activity of some plant extracts and their application in biscuits. Food Chemistry, 90, 317-321.

Shori, A. (2013). Antioxidant activity and viability of lactic acid bacteria in soybeanyogurt made from cow and camel milk. Journal of Taibah University for Science, , 7 , 202-208.

Sim, W.C., Lian, C.G. \& Aspollah, S.M. (2011). $\alpha$-mangostin dan $\beta$-mangostin from Cratoxylum glaucum. Research Journal Chemistry and Envirorment, 15, 62-66.

Toripah, S.S., Abidjulu, J. \& Wehantouw, F. (2014). Aktivitas antioksidan dan kandungan total fenolik ekstrak daun kelor (Moringa Oloefera Lam.). Pharmacon Jurnal Ilmiah Farmasi, 3. 37-43.

Winarsi, H. (2007). Antioksidan Alami dan Radikal Bebas. Yogyakarta: Kanisius.

Wong, K. M. (2007). Tree Flora of Sabah and Sarawak. Kuala Lumpur: Forest Research Institute Malaysia 